\title{
Sterilization potential of Ascaris lumbricoides eggs in the presence of different disinfectant agents
}

\author{
O potencial de esterilização de ovos de Ascaris lumbricoides na presença \\ de diferentes agentes desinfetantes
}

Fernando Sérgio Barbosa ${ }^{1}$; Mariela Helena Leite ${ }^{2}$; Mariana Teixeira de Faria ${ }^{1}$; Bruna de Alcântara Veloso Gontijo ${ }^{3}$; Guilherme Pereira Fontes²; Amanda Martins Severino $^{2}$; Ivani Pose Martins ${ }^{1}$.

${ }^{1}$ Professor(a) do Centro Universitário de Formiga. Formiga, Minas Gerais, Brasil.

${ }^{2}$ Graduando(a) do curso de Biomedicina pelo Centro Universitário de Formiga. Formiga, Minas Gerais, Brasil.

${ }^{3}$ Graduando(a) do curso de Medicina na Faculdade de Ciências Médicas e Saúde de Juiz de Fora SUPREMA, Juiz de Fora, Minas Gerais, Brasil.

\begin{abstract}
Introduction: Intestinal parasitic infections represent a public health problem, being responsible for high rates of morbidity and mortality. Ascaris lumbricoides is one of the main parasites prevalent in the community. The A. lumbricoides infection method is oral fecal cicle, in this sense, it is necessary to expand effective methods to prevent the ingestion of eggs, such as sanitation, cleansing habits or even effective methods for the sterilization of eggs. Objective: Evaluate different agents of antisepsis action, with the purpose of find which ones are more efficient in larval mortality inside eggs. Methodology: The parasites were provided by the Federal University of Minas Gerais, which were sectioned, in this way, the recovered eggs were kept in culture bottles. After 40 days, the embryonated eggs were purified and separated in culture bottles, and in each bottle had one different disinfectant products were added, in different concentrations and action time. As control, egg aliquots were maintained by adding distilled water. Using a microscope, it was observed the viability of the larvae inside. To determine the viability of the larvae, distilled water at $40{ }^{\circ} \mathrm{C}$ was added, then allowing the visualization of mobility inside the eggs. Results: It was observed that, in the fifteen disinfectant agents tested, only four showed efficacy, at intervals of 24 and 48 hours after exposure to the disinfectant and when undiluted. Conclusion: The data obtained in this study will contribute to the understanding of the epidemiology of this disease, as well as contributing to the development of more effective hygiene programs for the control of this parasitosis.
\end{abstract}

Keywords: Ascaris lumbricoides; Eggs; Sterilization.

Autor correspondente:

Fernando Sérgio Barbosa

Endereço: Rua Viena, 121

Recebido em: 12/11/2020

CEP: 35588-000-Arcos (MG), Brasil.

Revisado em: 16/11/2020

Aceito em: 03/02/2021

E-mail:fernandosergioba@gmail.com

Publicado em: 02/03/2021 


\section{Resumo}

Introdução: As parasitoses intestinais representam um problema de saúde pública, sendo responsáveis por altos índices de morbidade e mortalidade. A espécie Ascaris lumbricoides é um dos principais parasitos prevalentes na população. O método de infecção por A. lumbricoides é fecal oral, neste sentido, faz-se necessário a ampliação de métodos eficazes para evitar a ingestão de ovos, como saneamento, hábitos de higiene ou ainda métodos eficazes para a esterilização dos ovos. Objetivo: Avaliar diferentes agentes de ação desinfetante, com o intuito de encontrar quais são mais eficientes na mortalidade das larvas no interior dos ovos. Metodologia: Os parasitos foram cedidos pela Universidade Federal de Minas Gerais, os quais foram seccionados, os ovos recuperados foram mantidos em garrafas de cultura. Após 40 dias os ovos embrionados foram purificados, separados em garrafas de cultura, e em cada garrafa adicionou-se diferentes produtos desinfetantes, em diferentes concentrações e tempos. Como controle, alíquotas de ovos foram mantidas acrescendo água destilada. Com auxílio de microscópio foi observando a viabilidade das larvas no interior. Para a determinação de viabilidade das larvas, acrescentou-se água destilada à $40^{\circ} \mathrm{C}$, permitindo assim a visualização de mobilidade no interior dos ovos. Resultados: Observou-se que dos quinze agentes desinfetantes testados somente quatro demostraram eficácia, nos intervalos de 24 e 48 horas após a exposição ao desinfetante e quando não diluídos. Conclusão: Os dados obtidos neste estudo contribuirão para o entendimento da epidemiologia desta enfermidade como também poderá contribuir para o desenvolvimento de programas mais efetivos para o controle desta parasitose.

Palavras-chave: Ascaris lumbricoides; Esterilização; Ovos.

\section{Introduction}

Intestinal parasitosis represent a public health problem, especially in developing countries, being responsible for high morbidity and mortality rates ${ }^{1-3}$. Among intestinal parasites, Ascaris lumbricoides is considered one of the most prevalent species in the population and one of the main geo-helminths (STH) ${ }^{4-7}$. It's estimated that this parasite is responsible for contaminating approximately 800 million people ${ }^{8-10}$. Due to the scope of this disease and the massive number of infected people, it is safe to say that it is a parasitosis neglected by health authorities, especially because the majority of the victims are members of less favored population groups ${ }^{11-13}$.

Its occurrence is associated with a lack of hygiene habits, basic sanitation, as well as the geographical area ${ }^{14-16}$. Environmental conditions are extremely relevant for infectivity by the parasite. It is known that the eggs eliminated in the host's feces don't have an infection capacity, and in the environment, the larvae inside these eggs, develop and become infectious ${ }^{17}$. A. lumbricoides infection occurs through the ingestion of viable eggs, present mainly in contaminated water or food $^{18-20}$.

Therefore, prophylactic methods to prevent infection consist of ingesting treated water and food asepsis. However, many times the water used by the population is inefficiently treated with chlorine and other products. The A. lumbricoides eggs have a high capacity to survive the treatment of residual water and, as a result, the larvae inside these eggs remain alive, is considered one of the main epidemiological factors of the disease ${ }^{21-}$ 25 .

Also, another common practice in Brazil, used as a prophylactic method, consists of washing fruits and vegetables using hypochlorite (sanitary water) and acetic acid (vinegar). However, these practices are also not very 
effective in the prophylaxis of $A$. lumbricoides eggs, not killing larvae inside them, as observed by GazzinelliGuimarães et al. $(2018)^{26}$, where they used collective $A$. lumbricoides eggs in contact with these two agents, to be used in experimental bacteria in animals.

Thus, a factor that could contribute to the prophylaxis of this parasitosis would be the sterilization of eggs in the environment, in water treated by distribution centers, using disinfectant agents, and then filtered to be sent to the population. However, the concentration is not known, nor which agents can exterminate the larvae of $A$. lumbricoides inside the eggs ${ }^{27}$.

It is based on this perspective that the present study aimed to evaluate prophylactic methods for disinfection, using different types of disinfectant agents, to ascertain the death of the larvae inside the eggs of this parasite, to make them unviable for the contamination of human beings. The data collected to understand the epidemiology of ascariasis and assist in the development of more effective programs for prophylaxis and its control.

\section{Methodology}

The parasites were kindly provided by the Laboratory of Immunology and Parasite Genomics of the Institute of Biological Sciences (ICB), Department of Parasitology, Federal University of Minas Gerais (UFMG). Of these, three females were separated and fixed longitudinally on a styrofoam plate, with the aid of needles (BD Precision Glide ${ }^{\circledR} 0.45$ x 1326 G 1/2) positioned at the end of the parasites. Then, using a stylet no. 20 (Suzhoukyuan Medical Apparatus Co.), the females were sectioned longitudinally, the uterus was separated from the other organs and transferred to a porcelain crucible (Chiarrott, volume of $200 \mathrm{~mL}$ ) and added $3 \mathrm{~mL}$ of Phosphate Buffered Saline (PBS) $\mathrm{pH}$ 7.4. Subsequently, with the help of a porcelain stick, the uterus was macerated and the content filtered by Tamis (100micron spacing mesh) over a $200 \mathrm{ml}$ sedimentation cup, and the sediment content was awaited. After 40 minutes, the sediment was collected by a serological pipette and transferred to culture bottles (Thermo Fisher Scientific), with a capacity of $200 \mathrm{~mL}$ and added to $100 \mathrm{~mL}$ (PBS) $\mathrm{pH}$ 7.4. These cultures were manually shaken three times a week, for the embryonic of the eggs, which occurred in approximately 40 days, according to GazzinelliGuimaraes et al. $(2018)^{26}$.

After 40 days, the flasks containing the embryonated eggs kept in culture were homogenized, and $45 \mathrm{~mL}$ of the solution was removed with the aid of a serological pipette $(15 \mathrm{~mL}$ Serological pipet $)$ and transferred to conical tubes, with $50 \mathrm{~mL}$ capacity (Falcon tube $50 \mathrm{~mL}$ ). Then, the tubes were centrifuged (Hitachi, Himac CR 21) at $800 \mathrm{~g}$ for 10 minutes. The eggs were concentrated in the pellet, the supernatant was discarded and $45 \mathrm{~mL}$ of distilled water was added to each tube. This process was repeated three times to remove the PBS and purify the eggs. At the end of this step, a disinfectant product (TABLE 1) was added to each tube, in a certain concentration.

Disinfectants were purchased at random as long as they had some action described as germicidal or bactericidal on the product label, at commercial points and identified by codes, to create a trademark for each product. These products were diluted in distilled water, in the following rules: $25 \%, 50 \%, 75 \%$ and without dilution. The eggs were kept immersed in disinfectant products for 1 , 12,24 , and 48 hours. 
TABLE 1: Products with disinfectant action, demonstrating the characteristics of the tested products that were exposed to the embryonic eggs of $A$. lumbricoides.

\begin{tabular}{|c|c|c|}
\hline Product & Main active ingredient & $\begin{array}{l}\text { Activity indicated by } \\
\text { the manufacturer }\end{array}$ \\
\hline $\mathrm{P} 1$ & Hydrochloric acid $33 \%$ & Floor cleaning \\
\hline $\mathrm{P} 2$ & Sodium hypochlorite $2,0-2,5 \%$ & $\begin{array}{l}\text { Germicidal and } \\
\text { bactericidal }\end{array}$ \\
\hline $\mathrm{P} 3 *$ & $\begin{array}{l}\text { Sulfonic acid }(13,8 \%) \text {, hydrochloric acid }(0,03 \%) \text { e Nonylphenol } \\
\text { Ethoxylate }\end{array}$ & $\begin{array}{l}\text { Floor and ceramic } \\
\text { cleaning }\end{array}$ \\
\hline $\mathrm{P} 4$ & Hydrogen peroxide & Stain remover \\
\hline P5 & $\begin{array}{l}\text { Sodium linear alkylbenzene sulfonate }(5-15 \%) \text { e Sodium Lauryl } \\
\text { Ether Sulfate }(1-10 \%)\end{array}$ & Detergent \\
\hline P6* & Linear alkylbenzene sulphonate & $\begin{array}{l}\text { germicidal and } \\
\text { bactericidal }\end{array}$ \\
\hline P7 & $\begin{array}{l}\text { Nonylphenol Ethoxylates with 9,5 moles of ethylene oxide and laril } \\
\text { éter sulfato de sódio }\end{array}$ & General cleaning \\
\hline P8 & Sodium hypochlorite $(2,0 \%)$ e Sodium Lauryl Ether Sulfate & $\begin{array}{l}\text { germicidal and } \\
\text { bactericidal }\end{array}$ \\
\hline P9 & $\begin{array}{c}\text { Alkyl dimethyl benzyl ammonium chlorides }(0,25-0,3 \%) \text {, Didecyl } \\
\text { dimethyl ammonium chloride }(0,1-0,15 \%)\end{array}$ & $\begin{array}{l}\text { Germicidal and } \\
\text { bactericidal }\end{array}$ \\
\hline $\mathrm{P} 10$ & Acetic acid (Vinegar - $4 \%$ acidity) & $\begin{array}{l}\text { Used in cooking. } \\
\text { Trivially used as a } \\
\text { disinfectant }\end{array}$ \\
\hline $\mathrm{P} 11^{*}$ & $\begin{array}{c}\text { dimethyl coco benzyl ammonium chloride / Didecyl dimethyl } \\
\text { ammonium chloride }(0,45 \%) \text {, cetyltrimethylammonium chloride } \\
(0,35 \%) \text {. }\end{array}$ & $\begin{array}{l}\text { germicidal and } \\
\text { bactericidal }\end{array}$ \\
\hline $\mathrm{P} 12 *$ & Ortho-benzyl-para-chlorophenol $(0,42 \%)$ & $\begin{array}{l}\text { germicidal and } \\
\text { bactericidal }\end{array}$ \\
\hline P13 & Benzalkonium chlorid $(0,28 \%)$ & $\begin{array}{c}\text { Germicidal and } \\
\text { bactericidal }\end{array}$ \\
\hline P14 & Sodium Hydroxide $(49,0-50,0 \%)$ & Descaler \\
\hline P15 & Linear Dodecylbenzene Sulfonic Acid $96 \%$ & General cleaning \\
\hline
\end{tabular}

*Products that have demonstrated effectiveness in the non-viability of eggs.

As a positive control, aliquots of $A$. lumbricoides eggs without exposure to disinfectant products were used, where they were kept only in contact with distilled water at room temperature. As a negative control, distilled water at $100^{\circ} \mathrm{C}$ was added to the eggs, and left until it reached room temperature, which this method prevents the larvae inside the eggs.

After the determined time, the eggs were purified. For this, the solution where the eggs and the disinfectant product were kept was centrifuged for 10 minutes, at $800 \mathrm{~g}$. The supernatant was discarded, and to the pellet, $45 \mathrm{ml}$ of water was added at $40^{\circ} \mathrm{C}$ and homogenized. Subsequently, $20 \mu \mathrm{l}$ of the solution containing approximately 1000 eggs was removed, with the aid of a micropipette (Gilson 10-100 $\mu$ l) and placed on a slide/cover slip and analyzed under an optical microscope, with a 400-fold magnification. The eggs were counted in duplicate by two researchers, where the larvae were observed inside the eggs.

To analyze the viability of the eggs, it was observed the larvae mobility inside them, presenting an intense movement due to the temperature change. 
Therefore, when the larvae remain alive, they show movement, and when dead, no movement was observed. The positive and negative control groups were also analyzed. Through these analyzes, it was possible to identify which disinfecting agents are effective and at what concentrations make the eggs unfeasible.

The data were tabulated and processed in spreadsheets prepared in Microsoft Excel. The results obtained were interpreted using quantitative analysis for the later elaboration of the graphics.

\section{Results}

When analyzing the viability of the eggs, after exposure to the various products, it was observed that of the 15 disinfectant products tested, only four showed efficacy. Products P3 and P6 had an action within 24 hours of exposure to eggs, and products P11 and P12, within 48 hours (FIGURE 1).

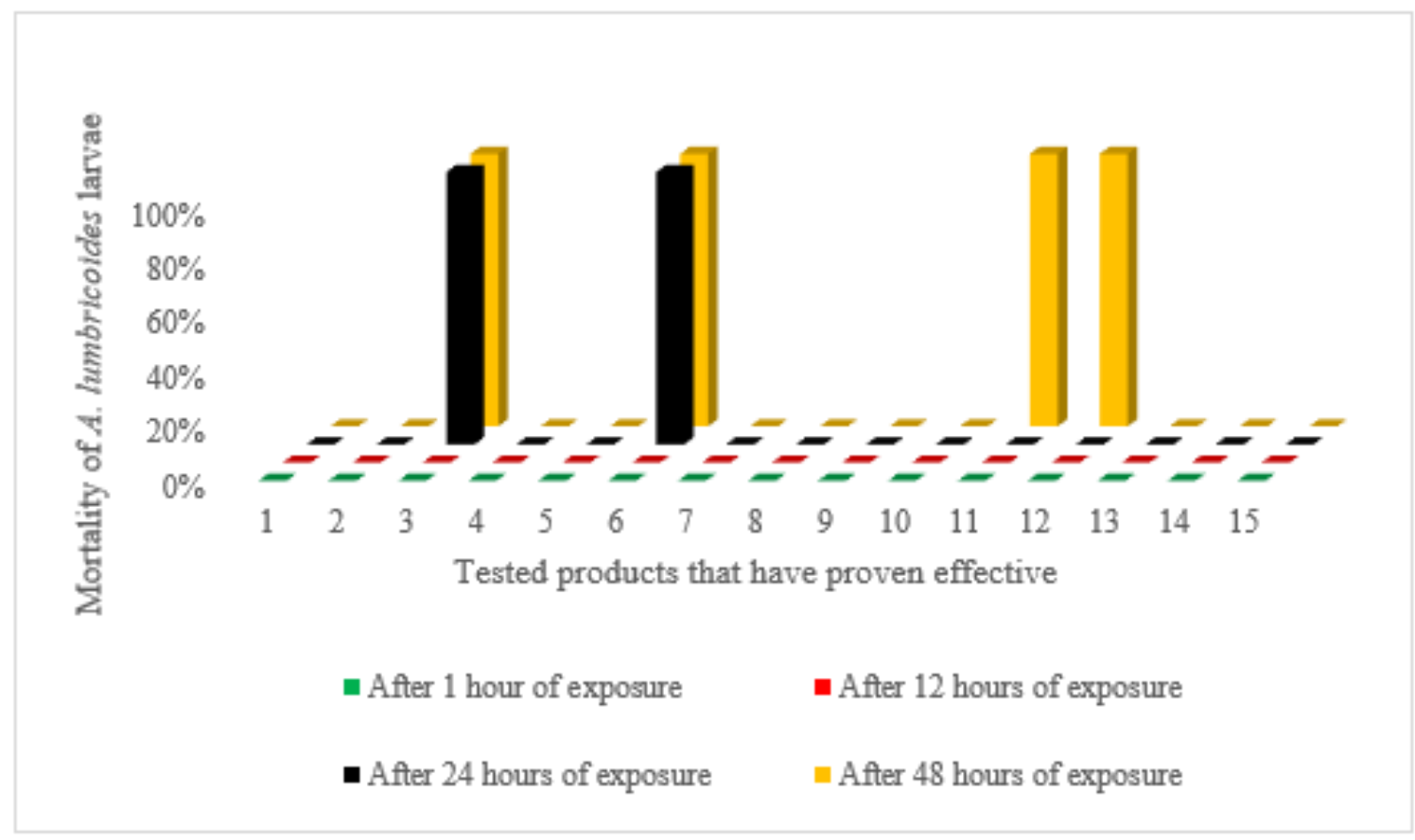

FIGURE 1 - Disinfectant products that demonstrated efficacy in larvae unfeasibility inside Ascaris lumbricoides eggs regarding the time of exposure.

The products that demonstrated efficacy regarding the larvae's unfeasibility only showed effects when they were used without dilution. The other tested products did not generate any deleterious effect on the larvae, regardless of the exposure time evaluated.

When analyzing the dilution concentrations of the disinfectants used, no product showed efficacy when diluted by $25 \%, 50 \%$, and $75 \%$. Only products P3, P6, P11, and P12 demonstrated effectiveness when they were not diluted (FIGURE 2). 


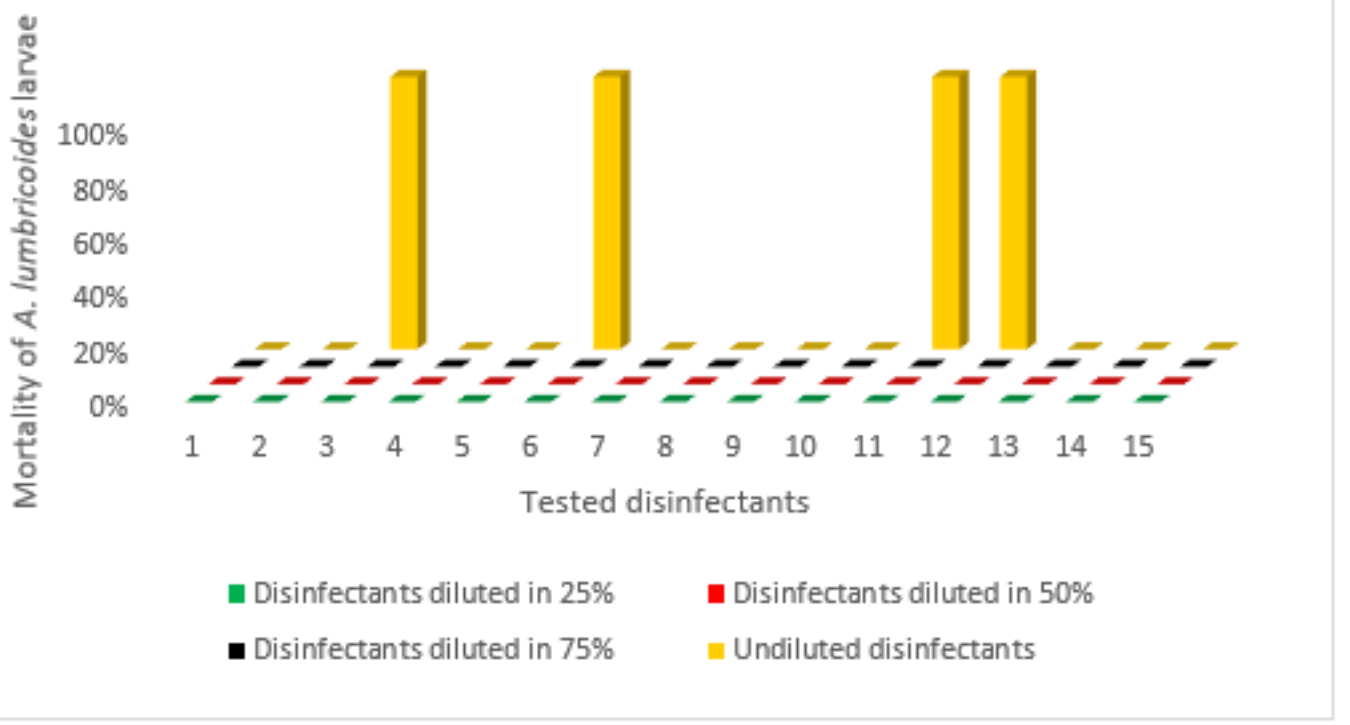

FIGURE 2 - Disinfectant products that demonstrated efficacy in the larvae inviability inside Ascaris lumbricoides eggs regarding dilution or non-dilution of the product.

It was possible to observe that the larvae in the positive control group were alive and showed movements inside the eggs when water was added at $40^{\circ} \mathrm{C}$. This fact proves the validation of the control, being an extremely important factor to confirm the viability of the larvae inside the eggs. In the negative control, the larvae did not show any movement when $40^{\circ} \mathrm{C}$ water was added, since all the larvae were dead (FIGURE 3).

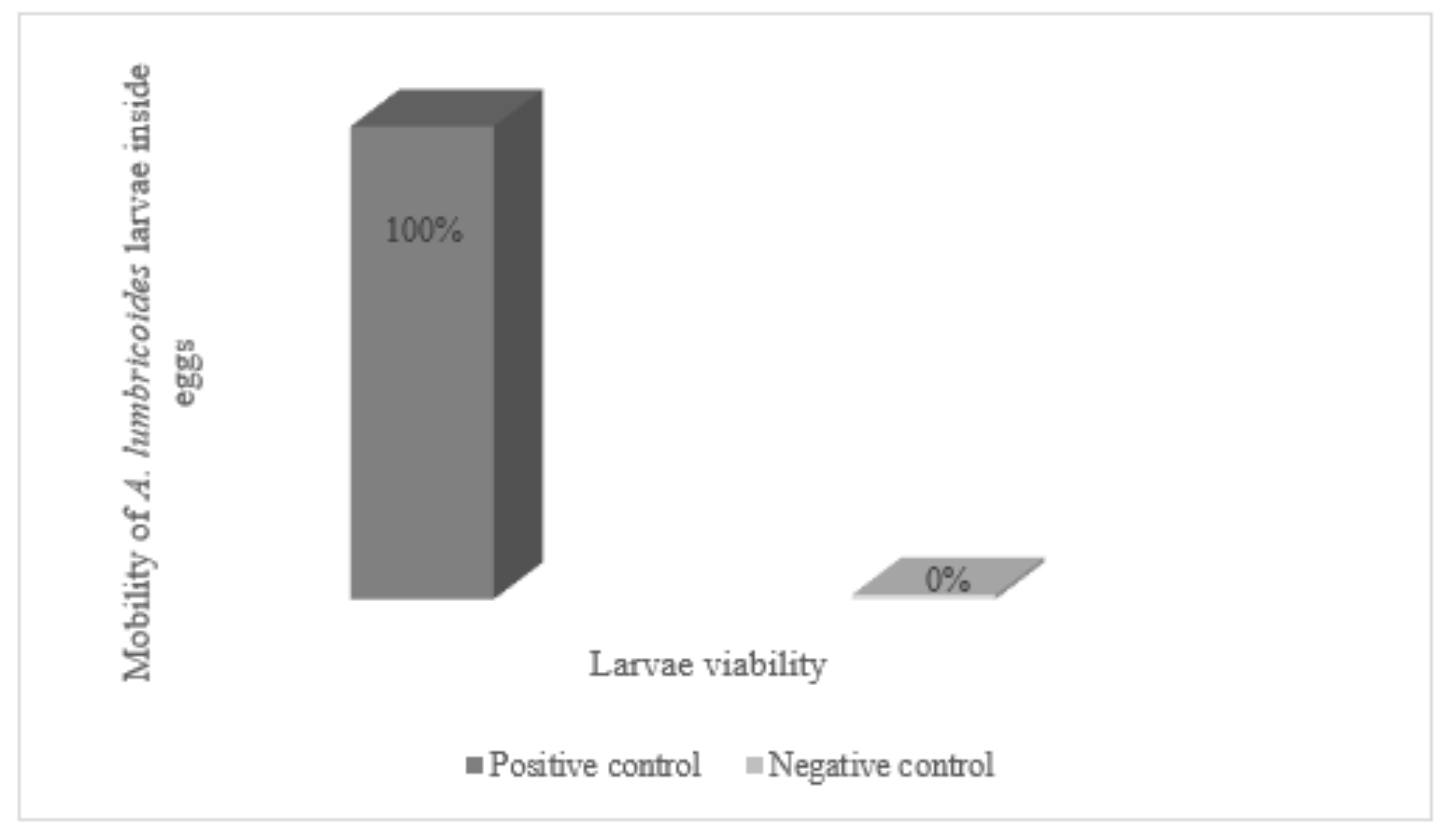

FIGURE 3 - Positive control group and negative control group of the larvae of Ascaris lumbricoides regarding their mobility inside the eggs.

\section{Discussion}

In the present study, the results showed that $A$. lumbricoides eggs have great resistance. Thereby, it is understood that to eliminate the infectious forms and control the frequency of this parasitosis, it is necessary to find more efficient methods. 
The reason why $A$. lumbricoides eggs are so resistant is probably because they have several layers, which are essential for the protection and development of the larva inside. Gazzinelle-Guimaraes et al. $(2013)^{28}$ and Barbosa (2015) $)^{21}$ used A. lumbricoides and A. suum eggs grown in $5 \%$ hypochlorite and 0.2 molar sulfuric acid in experimental infections in mice, swine and humans and realized that the eggs did not suffer any interference in the experiments and remained viable, infecting animals and humans.

Therefore, this study made an evaluation for the analysis of several techniques for the disinfection and death of the larvae inside the eggs, using disinfectant products. The data found show that few products have shown effectiveness when it comes to making them unviable to contamination. However, it is important to highlight that the analyzed products are marketed and indicated for domestic use in diluted and not pure form, so the appropriate dilutions were used to simulate this use.

Two products tested in this study, pine-based, demonstrated success in the impracticability of $A$. lumbricoides eggs. These findings corroborate the data by Massara et al. $(2003)^{29}$. However, other products tested in the present study, also based on pine, had no sterilizing effect. This fact may be related to the disinfectant produced by the manufacturer having a lower concentration of the active principle, which may be involved in the mortality of the larvae.

Other products that have shown efficiency in terms of larval mortality have Sulphonic Acid and Alkibenzene Acid as an active ingredient. These products probably showed efficacy due to their high acidity, which contributed to the larvae inviabilityy inside the eggs.

In the study results of Massara et al. $(2003)^{29}$ using eggs of A. lumbricoides and in the studies of Morera $(1986)^{30}$; Zanini \& Graeff-Teixeira $(1995)^{31}$, using Angiostrongylus costaricensis larvae, some detergent brands and acetic acid did not demonstrate efficacy regarding the larvae unfeasibility of the analyzed parasites. In the present study, the other detergents and acetic acid also did not interfere in the mortality of $A$. lumbricoides larvae. However, in the studies of Zanini \&
Graeff-Teixeira $(1995)^{31}$ that used the parasite $A$. costaricensis as a model, the effectiveness of sodium hypochlorite was observed, differently from what was observed in the present study, which did not observe efficacy in the mortality of A. lumbricoides larvae, corroborating with the studies by Massara et al. $(2003)^{29}$.

In this study, the resistance of A. lumbricoides eggs to different disinfectant agents was demonstrated, in which the larvae remained viable for most of the agents tested. The products that showed efficacy were not diluted, and the time that the eggs of A. lumbricoides were exposed to the product and showed efficacy in larval mortality was much longer than indicated by the manufacturer. This makes the unfeasibility of $A$. lumbricoides eggs a problem.

Therefore, new products must be tested to understand the efficacy of these disinfectants as a prophylactic measure for A. lumbricoides eggs, as well as for eggs and cysts of other parasites, since the products routinely for domestic use do not remain for the time necessary for the impracticability of $A$. lumbricoides eggs as demonstrated in the present study. However, the data obtained in this study may contribute to a better understanding of the epidemiology of these parasites and assist in the development of more effective programs for their control.

\section{Conclusion}

A. lumbricoides eggs are extremely resistant and adapted to the adversities of the environment. This is observed because most of the tested products do not have the ability to kill the larva inside these eggs, with this, once in the environment, they can hardly be successfully removed. These results emphasize the need to reevaluate the prophylactic methods already routinely adopted in food hygiene and cleaning in general when the aim is to prevent A. lumbricoides infection, since most procedures are not efficient to combat them. 
References

1. ZHOU, C; JIAN, S; PENG, W; LI, M. Genetic Diversity of Ascaris in China Assessed Using Simple Sequence Repeat Markers. Korean Journal of Parasitology, v. 56, n. 2, p. 175-181, 2018.

2. MONTEIRO, K. J. L.; CALEGAR, D. A.; SANTOS, J. P., BACELAR, P. A. A.; CORONATO-NUNES, B.; REIS, E. R. C.; BOIA, M. N.; CARVALHO-COSTA, F. A.; JAEGER, L. H. Genetic diversity of Ascaris spp. infecting humans and pigs in distinct Brazilian regions, as revealed by mitochondrial DNA. PLoS One, v. 14, n. 6, p. 1-13, 2019.

3. FOWLER, A. C.; HOLLINGSWORTH, T. D. The dynamics of Ascaris lumbricoides infections.

Bulletin of Mathematical Biology, v. 78, n. 4, p. 815-833, 2016.

4. WEI, J.; VERSTEEG, L; LIU, Z.; KEEGAN, B.; GAZZINELLI-GUIMARÃES, A. C.; FUJIWARA, R.T.; BRIGGS, N.; JONES, K. M.; STRYCH, U.; BEAUMIER, C.M.; BOTTAZZI, M. E.; HOTEZ, P. J.; ZHAN, B. Yeast-expressed recombinant As16 protects mice against Ascaris suum infection through induction of a Th2-skewed immune response. PLoS Neglected Tropical Diseases, v. 11, n. 7, p. 1-20, 2017.

5. KHURANA, S.; SETHI, S. Laboratory diagnosis of soil transmitted helminthiasis. Tropical

Parasitology, v. 7, n. 2, p. 86-91, 2017.

6. BUENDÍA, E.; ZAKZUK, J.; MERCADO, D.; ALVAREZ, A.; CARABALLO, L. The IgE response to Ascaris molecular components is associated with clinical indicators of asthma severity. The World Allergy Organization Jornal, v. 8, n. 1, p.1-11, 2015.
7. SHAO, C. C; XU, M. J.; ALASAAD, S.; SONG, H. Q.; PENG, L.; TAO, J. P.; ZHU, X. Q.

Comparative analysis of microRNA profiles between adult Ascaris lumbricoides and Ascaris suum. BMC Veterinary Research, v. 10, n. 1, p. 16, 2014.

8. JEANDRON, A.; ENSINK, J. H. J.; THAMSBORG, S. M.; DALSGAARD. A.; SENGUPTA, M. E. A Quantitative Assessment Method for Ascaris Eggs on Hands. PLoS ONE, v. 9, n. 5, p. 1-6, 2014.

9. HOTEZ, P. J; ALVARADO, M.; BASÁÑEZ, M. G.; BOLLIGER, I.; BOURNE, R.; BOUSSINESQ, M.; et al. The Global Burden of Disease Study 2010: Interpretation and Implications for the Neglected Tropical Diseases. PLoS Neglected Tropical Diseases, v. 8, n. 7, p. 28-65, 2014.

10. VOS, T.; ABAJOBIR, A. A.; ABBAFATI, C.; ABBAS K. M.; ABATE, K. H.; ABD-ALLAH, F.; ABDULLE, A. M. Global, regional, and national incidence, prevalence, and years lived with disability for 328 diseases and injuries for 195 countries, 1990-2016: a systematic analysis for the Global Burden of Disease Study 2016. The Lancet, v. 390, n. 10100, p. 1211-1259, 2017.

11. FREIRE, J.; CARNEIRO, M. A.; CARNEIRO, J. G.; MELO, M. V. C. Incidência de Ascaris lumbricoides em mulheres de três bairros de Fortaleza-CE, Brasil. Revista Diálogos Acadêmicos, v. 1, n. 1, p. 59-65, 2012.

12. CAVALLERO, SNABEL, V.; PACELLA, F.; PERRONE, V.; D'AMELIO, S. Phylogeographical Studies of Ascaris spp. Based on Ribosomal and Mitochondrial DNA Sequences. PLoS Neglected Tropical Diseases, v. 7, n. 4, p. 1-9, 2013. 
HUGHES, J.; GRIFFIN, C.; ATUHAIRE, A.; ARINAITWE, M.; ADRIKO, M.; RUGGIANA, A.; TURYAKIRA, G.; KABATEREINE, N. B.; STOTHARD, J. R. Uganda Genetic diversity of Ascaris in southwestern Uganda. Transactions of the Royal Society of Tropical Medicine and Hygiene, v. 106, n. 2, p. 75-83, 2012.

14. DOLD, C.; HOLLAND, C. V. Ascaris and ascariasis. Microbes and Infection, v. 13, n. 7, p. 632-637, 2011

15. BUSATO, M. A.; ANTONIOLLI, M. A.; TEO, C. R. P. A.; FERRAZ, L.; POLI, G., \& TONINI, P. Relação de parasitoses intestinais com as condições de saneamento básico. Ciência, Cuidado e Saúde, v. 13, n. 2, p. 357-363, 2014.

16. BENDALL, R. P.; BARLOW, M.; BETSON, M.; STOTHARD, J. R.; NEJSUM, P. Zoonotic ascariasis, United Kingdom. Emerging Infectious Diseases, v. 17, n. 10, p. 1964-1966, 2011.

17. CAMPOS, M. R.; VALENCIA, L. I. O.; FORTES, B. P. M. D.; BRAGA, R. C. C. B.; MEDRONHO, R. A. Distribuição espacial da infecção por Ascaris lumbricoides. Revista de Saúde Pública, v. 36, n. 1, p. 69-74, 2005.

18. BETSON, M.; NEJSUM, P.; BENDALL, R. P.; DEB, R. M.; STOTHARD, J. R. Molecular Epidemiology of Ascariasis: A Global Perspective on the Transmission Dynamics of Ascaris in People and Pigs. Journal of Infectious Diseases, v. 210, n. 6, p. 932-941, 2014.

19. STEINBAUM, L.; KWONG, L. H.; ERCUMEN, A.; NEGASH, M. S.; LOVELY, A. J.; NJENGA, S. M.; BOEHM, A. B.; PICKERING, A. J.; NELSON, K. L. Detecting and enumerating soil-transmitted helminth eggs in soil: New method development and results from field testing in Kenya and
Bangladesh. PLoS Neglected Tropical Diseases, v. 11, n. 4, p. 1-15, 2017.

20. SOARES, A. L.; NEVES E. A. O.; SOUZA I. F. A. C. A Importância da Educação Sanitária no Controle e Prevenção ao Ascaris lumbricoides na Infância. Cadernos de Graduação. Ciências Biológicas e de Saúde Unit, v. 3, n. 3, p. 23-32, 2018.

21. BARBOSA, F. S. Potencial Zoonótico da Ascaridiose Humana e Suína : Aspectos Moleculares, Morfológicos e Filogenéticos das Espécies Ascaris lumbricoides e Ascaris Suum. In:Tese doutorado, Instituto de Ciências Biológicas, Universidade Federal de Minas Gerais, Belo Horizonte, 2015.

22. CRUZ, L. M.; ALLANSON, M.; KWA, B.; AZIZAN, A.; IZURIETA, R. Morphological Changes of Ascaris spp. Eggs During Their Development Outside the Host. Journal of Parasitology, v. 98, n. 1, p. 63-68, 2012.

23. SOTO, L. A.; SANTÍSIMA-TRINIDAD, A. B.; BORNAY-LLINARES, F. J.; GONZÁLEZ, M. M.; ANTONIO J, VALERO, J. A. P.; MUÑOZ M. R. Quantitative PCR and Digital PCR for Detection of Ascaris lumbricoides Eggs in Reclaimed Water.

BioMed Research International v. 2017, p. 9-32, 2017.

24. RAVINDRAN, V. B.; SURAPANENI, A.; CROSBIE, N. D.; SCHMIDT, J.; SHAHSAVARI, E.; HALEYUR, N.; SONI, S. K.; BALL, A. S. A modified approach to recover and enumerate Ascaris ova in wastewater and sludge. PLOS Neglected Tropical Diseases, v. 13, n. 2, 2019.

25. AMOAH, I. D.; ADEGOKE, A. A.; AXEL, T. Soiltransmitted helminth infections associated with 
wastewater and sludge reuse : a review of current evidence. Tropical Medicine and International

Healtv., v. 23, n. 7, p. 692-703, 2018.

26. GAZZINELLI-GUIMARÃES, A. C.; GAZZINELLI-GUIMARÃES, P. H.; SILVA, F. N.; MATI, V. L.; DHOM-LEMOS, L. C.; BARBOSA, F. S.; PASSOS, L. S.; OLHAR, S.; CARNEIRO, C. M.; BARTHOLOMEU, D. C.; BUENO, L. L.; FUJIWARA R. T. IgG Induced by Vaccination With Ascaris suum Extracts Is Protective Against Infection. Frontiers in Immunology, v. 9, n. 2535, p. 1-15, 2018.

27. OH, K. S; KIM, G.; AHN, K.; SHIN, S. Effects of Disinfectants on Larval Development of Ascaris suum Eggs. Korean Journal of Parasitology, v. 54, n. 1, p. 103-107, 2016. Disponível em: <http://dx.doi.org/10.3347/kjp.2016.54.1.103 > . Acesso em 17 de abril de 2019.

28. GAZZINELLI-GUIMARÃES, P. H.; SOUZAFAGUNDES, E. M; CANCADO, G. G; MARTINS, V. G.; DHOM-LEMOS, L. C.; RICCI, N. D.; FIUZA, J. A.; BUENO, L. L.; MIRANDA, R. R; GUATIMOSIM. S.; GAZZINELLI, A.; CORREA-OLIVEIRA, R.; BARTHOLOMEU, D. C.; FUJIWARA, R. T. Cell apoptosis induced by hookworm antigens: a strategy of immunomodulation. Frontiers in Bioscience, v. 5, p. 662-675, 2013.

29. MASSARA, C. L.; FERREIRA, R. S.; ANDRADE, L. D.; GUERRA, H. L.; CARVALHO, O. S. Atividade de detergentes e desinfetantes sobrea evolução dos ovos de Ascaris lumbricoides.

Cadernos de Saúde Pública, v. 19, n. 1, p. 335340, 2003.

30. MORERA, P. Angiostrongilíasis abdominal: Transmisión y observaciones sobre su posible control. Control y erradicación de enfermedades infecciosas. In: Simposio Internacional
OMS/OPS, Resúmenes, pp. 230-235, Série de Copublicaciones de la OPS 1, Washington, DC: Organización Panamericana de la Salud. 1986.

31. ZANINI, G. M. \& GRAEFF-TEIXEIRA, C. Angiostrogilíase abdominal: profilaxia pela destruição das larvas infectantes em alimentos tratados com sal, vinagre ou hipoclorito de sódio.

Revista da Sociedade Brasileira de Medicina

Tropical, v. 28, p. 389-392, 1995. 